\title{
ПРОГРАМНИЙ ТУРИЗМ: ОРГАНІЗАЦІЯ РЕКРЕАЦІЙНИХ ПОСЛУГ В УМОВАХ СТАЛОГО РОЗВИТКУ ІНФРАСТРУКТУРИ ТУРИЗМУ (ПИТАННЯ ПРОЄКТУВАННЯ, ДИВЕРСИФІКАЦІї, КРЕАТИВНОСТІ, КЛАСТЕРИЗАЦІї)
}

\section{PROGRAM TOURISM: ORGANIZATION OF RECREATIONAL SERVICES IN THE CONTEXT OF CONTINUOUS DEVELOPMENT OF TOURISM INFRASTRUCTURE (THE ISSUE OF DESIGN, DIVERSIFICATION, CREATIVITY, CLUSTERING)}

\author{
Безкоровайна Лариса Вікторівна \\ доктор педагогічних наук, доцент, \\ Запорізький національний університет \\ ORCID: https://orcid.org/0000-0001-9502-9604 \\ Пиптюк Павло Федорович \\ кандидат педагогічних наук, доцент, \\ Запорізький національний університет \\ ORCID: https://orcid.org/0000-0002-8188-2046 \\ Наздравецька Вікторія Романівна \\ магістр, \\ Запорізький національний університет \\ ORCID: https://orcid.org/0000-0002-7212-1652
}

\section{Bezkorovayna Larysa, Pyptiuk Pavlo, Nazdravetska Viktoriia Zaporizhia National University}

\footnotetext{
3'ясовано, що вплив туризму як потужного механізму забезпечення соціально-економічного піднесення держави допустимий завдяки розвитку внутрішнього та в"їзного туризму, що потребує проєктування нового туристичного продукту (туру, маршруту, послуги), організації рекреаційних послуг адекватно всесвітнім та європейським тенденціям із урахуванням національних та регіональних властивостей. Визначним і далекосяжним шляхом для розвитку туристичної галузі в Україні, зважаючи на європейську практику диверсифрікації надання рекреаційних послуг, служить становлення таких видів туризму, як: сільський, зелений, агротуризм, що відповідає дотриманню гармонійності між економічними, соціокультурними, політичними, екологічними площинами.
}

Ключові слова: програмний туризм, організація рекреаційних послуг, сталий розвиток туризму, диверсифрікація, креативність, кластеризація

Проанализировано, что влияние туризма как мощного механизма обеспечения социально-экономического подъема государства возможно благодаря развитию внутреннего и въездного туризма, что требует проектирования нового туристического продукта (тура, маршрута, услуги), организации рекреационных услуг адекватно всемирным и европейским тенденциям с учетом национальных и региональных особенностей. Важным элементом для развития туризма в Украине, учитывая европейскую практику диверсисрикации предоставления рекреационных услуг, является становление таких видов туризма, как: сельский, зеленый, агротуризм, которые отвечают соблюдению сбалансированности между экономическими, социокультурными, политическими, экологическими аспектами и на сегодня являются стратегическим вектором мировой политики в области туризма.

Ключевые слова: программный туризм, организация рекреационных услуг, устойчивое развитие туризма, диверсифрикация, креативность, кластеризация. 
The article confirms that the urgency of the problem is determined by the process of integration of Ukrainian society into the European tourist area, one of the strategic goals of which is sustainable tourism development, based on the principles of establishing a harmonious balance between environmental, economic, social, cultural areas. It is analyzed that Ukraine has a great opportunity for tourism development in many areas: gastrotourism, ecotourism, medical tourism, business tourism, scientific tourism, rural tourism, recreational tourism, sea tourism, sports and health tourism, cultural tourism, MICE (Meetings, Incentives, Conferences, Events) and so on. The authors of the article analyzed the role of the tourism industry in the general situation and trends of the world economy, increasing employment, diversification and innovation of the national economy, preservation and growth of cultural reserves and environmentally friendly environment, harmonization of relations between countries and people confirmed by regulations at the global and national levels. The reasons that hinder the effective updating of the content of the tourist product for domestic and inbound tourism, namely: the lack of coordinated action of all industries that directly or indirectly ensure the functioning and growth of the tourism industry, system and integration approach in combining joint efforts to ensure growth of domestic and inbound tourism in Ukraine. It was found that the influence of tourism as a powerful mechanism for socio-economic prosperity of the state is permissible due to the development of domestic and inbound tourism, which requires the design of a new tourist product (tour, route, service), organization of recreational services adequate to global and European trends. national and regional properties. It is established that a significant and far-reaching way for the development of the tourism industry in Ukraine, given the European practice of diversification of recreational services, is the formation of such types of tourism as rural, green, agritourism, which corresponds to harmony between economic, sociocultural, political, environmental areas, and today is a strategic vector of world policy in the tourism industry.

Keywords: program tourism, organization of recreational services, sustainable development of tourism, diversification, creativity, clustering.

Постановка проблеми. Актуальність проблеми визначається процесом інтегрування нашої країни в європейський туристичний терен, однією із стратегічних цілей якого $є$ сталий розвиток туризму, заснований на принципах встановлення гармонійного балансу між екологічними, економічними, соціальними, культурними площинами адекватно до глобальних 17 цілей сталого розвитку до 2030 (2015); кліматичної угоди (2015); стратегії водної рамкової директиви (2000) та ін.

Слід підкреслити, що Україна на сьогодні має величезну можливість для розвитку туризму в багатьох спрямуваннях, а саме: гастротуризм, екотуризм, медичний туризм, діловий туризм, науковий туризм, сільський туризм, рекреаційний туризм, морський туризм, спортивно-оздоровчий туризм, культурний туризм, MICE (Meetings, Incentives, Conferences, Events) тощо.

Роль туристичної галузі в загальному становищі та тенденціях всесвітньої економіки, підвищенні рівня зайнятості, диверсифрікації та інноваційності національної економіки, збереженні й розросту культурного запасу та екологічно безпечного навколишнього природного оточення, гармонізації взаємовідносин між країнами і людьми, виконування зовнішньої політики держави, підтверджено нормативними паперами на державному (Закон України «Про зайнятість населення» (2013), Стратегія розвитку туризму та курортів до 2026 року (2017), Концепція популяризації України у світі та просування інтересів України у світовому інсрормаційному просторі (2018) та ін.) рівні.
Вплив туризму як повносилого механізму забезпечення соціально-економічного піднесення країни або регіону можливий завдяки розвитку внутрішнього та в"їзного туризму, що потребує проєктування новітнього туристичного продукту (туру, маршруту, обслуговування), організації рекреаційних послуг відповідно до всесвітніх та європейських тенденцій із урахуванням національних та регіональних властивостей, що підтверджено положеннями Закону України «Про внесення змін до деяких законодавчих актів України щодо державної підтримки сорери культури, креативних індустрій, туризму, малого та середнього бізнесу у зв'язку з дією обмежувальних заходів, пов'язаних із поширенням коронавірусної хвороби COVID-19 (2020).

Серед причин, що заважають ефективному оновленню контенту туристичного продукту для внутрішнього та в'їзного туризму, можна виділити такі, як: брак скоординованих дій усіх галузей, що прямо або опосередковано забезпечують функціонування та розріст індустрії туризму, системного та інтеграційного підходу в об'єднанні сумісних намагань щодо забезпечення розросту внутрішнього та в"їзного туризму в Україні.

Результативним інструментом для виробництва нового туристичного продукту на сьогодні служать інноваційні кластери, що сполучають різноманітні організації (органи державного керівництва, підприємства, товариства, заклади вищої освіти, громадські товариства тощо) 3 ціллю синергічної кооперації, що надає перспективу для більш швидкого 
реагування на запитання ринку, користуватися перевагами ринкового механізму, ефективно запроваджувати нові знання, нововведення, наукові відкриття в галузі туризму.

Слід зазначити, що до розросту критичного становища через пандемію COVID-19 у 2020 р. розпочалося усталене підвищення зацікавленості споживачів до туристичної галузі. Зацікавленість туристів особливо стосується таких найсучасніших видів туристичної діяльності, як: екотуризм, зелений туризм, агротуризм, сільський туризм. Такий спосіб надання рекреаційних послуг є наразі затребуваним на туристичному ринку послуг як для виїзного, так і для в"їзного та внутрішнього видів туризму.

Аналіз останніх досліджень і публікацій. У межах висвітлення проблеми із обраної теми на увагу заслуговують роботи, присвячені різноманітним аспектам туризму, таких учених, як: К. Аннару, Дж. Боуен, Ч. Голднер, І. Зорін, T. Кавєріна, Т. Квартальнов, О. Любіцева, Дж. Майкенз, Р. Макінтош, М. Мальська, Б. Рітчі та ін. Теоретичні та методологічні основи розвитку бізнесу та надання туристичних та рекреаційних обслуговувань на сільських територіях знайшли віддзеркалення у роботах таких науковців, як: М. Фортунато та П. Альтер (акцентують, що підприємницькі потенції вбудовані не лише в первинному досвіді та знаннях бізнесмена, а ще й у побудові та природі суспільства, його культурі); П. Джулієн (показує, що розрізнення в місцевій та регіональній культурі характеризують ступінь розвитку бізнесу на осібних територіях) [3, с. 20].

Водночас як традиційні розвідки полікультурної діяльності сільського туризму сфокусовано навколо мотивів її започаткування та наслідків ведення особистісних рис, теоретичні підходи до вивчення диверсифікації сільського бізнесу, фракторів, що впливають на цей процес, мають макро- та мікрорівневі аспекти [3, с. 20].

Як підтверджує теоретичний аналіз, Дж. Девіс та Д. Пірс від'єднують спонукальні (зростання чисельності населення; нерівний доступ до земельних ресурсів; обмеженість ринків вхідних ресурсів; низька рентабельність фрермерської практики; зменшення об'ємів природних ресурсів тощо) та стимулюючі (вищий рівень продуктивності роботи та інвестицій у несільськогосподарському підприємництві, нижчий ступінь ризику відносно сільськогосподарського підприємства; стремління до урбаністичного способу існування, особливо у молоді; генерування доходів для забезпе- чення матеріальних вимог) фрактори. Притаманним для багатьох досліджень диверсифрікації у сільській економіці є погляд на неї її як на стратегію мінімізації небезпек: кліматичних, біологічних; скорочення сільськогосподарської зайнятості та зростання напруги на ринку праці; незручних коливань кон'юнктури ринку та ступеня прибутковості підприємства, услід соціально-економічної стабільності галузі та сільського піднесення [3, с. 20].

Формулювання цілей дослідження. Мета статті полягає у з'ясуванні особливостей організації рекреаційних послуг в умовах сталого розвитку туризму; розкритті питань диверсифрікації, нових креативних фрорм туризму та кластеризації.

Виклад основного матеріалу дослідження 3 повним обґрунтуванням здобутих наукових результатів. На сьогодні індустрія туризму швидко змінюється й зростає, розлягаються новітні види їі діяльності, нові місця призначення, новітні технології, сучасні туристичні ринки. Величезна кількість туристів мандрують всесвітом, для них розробляються різноманітні туристичні пакети, круїзи, індивідуальні маршрути.

Зазначене продукує туристичну практику, перетворює суспільне життя, впливає на економіку, соціальний, культурний розвиток будьякої країни, туристичної локації.

Оскільки індустрія туризму $є$ глобальним підприємництвом, що продовжує нарощуватися, в українському суспільстві увага має приділятися проблемам навколишнього середовища, культурним та економічним питанням, створенню привабливих для туристів краєвидів та рекреаційних об'єктів. Задоволення зростання туристичної галузі за рахунок добре спланованого, екологічно нешкідливого піднесення $€$ складним дорученням для планування всесвіту [2, с. 35-36].

Враховуючи вищезазначене, слід підкреслити, що наразі важливим і перспективним напрямом для розвитку туристичної галузі в Україні, зважаючи на європейський досвід диверсиорікації надання рекреаційних послуг із метою сталого розвитку туризму слугує становлення таких видів туризму, як сільський, зелений, агротуризм, що відповідає дотриманню гармонійності між економічними, соціокультурними, політичними, екологічними аспектами, і на сьогодні $€$ стратегічним вектором світової політики в галузі туристичної індустрії.

Як підтверджують результати порівняльного аналізу статистичних показників, 
Таблиця 1

Економічні показники діяльності сільського зеленого туризму в Україні 2012-2017 рр.

\begin{tabular}{|l|c|c|c|c|c|}
\hline \multicolumn{1}{|c|}{ Показник } & $\mathbf{2 0 1 2}$ & $\mathbf{2 0 1 3}$ & $\mathbf{2 0 1 4}$ & $\mathbf{2 0 1 7}$ & $\begin{array}{c}\text { Коефріцієнт } \\
\text { 3ростання/ } \\
\text { 3меншення } \\
\mathbf{2 0 1 7 / 2 0 1 2}\end{array}$ \\
\hline $\begin{array}{l}\text { Доходи від наданих послуг } \\
\text { (без ПдВ, акцизного податку і } \\
\text { аналогічних платежів), тис. грн. }\end{array}$ & 10189,7 & 16966,7 & 11219,9 & 53594,4 & 5,26 \\
\hline $\begin{array}{l}\text { Фактичні витрати на один людино- } \\
\text { день перебування, грн. }\end{array}$ & 117,2 & 104,4 & 117,8 & 248,1 & 2,12 \\
\hline Кількість ночівель, од. & 112520 & 130695 & 93341 & 213061 & 1,89 \\
\hline $\begin{array}{l}\text { Середня тривалість перебування } \\
\text { розміщених осіб, діб }\end{array}$ & 2,2 & 2,6 & 2,4 & 2,6 & 1,18 \\
\hline $\begin{array}{l}\text { Коефріцієнт використання місткості } \\
\text { садиб }\end{array}$ & 0,26 & 0,19 & 0,15 & 0,2 & 0,77 \\
\hline
\end{tabular}

Джерело: побудовано авторами за даними [4]

викладених у нормативних документах за 2013-2017 рр., розвиток зеленого (сільського) туризму в Україні характеризується певними позитивними тенденціями.

Як переконують дані таблиці 1, у 2013 р. доходи від надання сервісів збільшились на 6777 тис. грн., або 66,5\%, відносно з 2012 р. Водночас збільшилися господарські затрати адекватно на 5236,4 тис. грн., або в 1,04 рази. За проаналізований етап доходи перевершують витрати, що підтверджує отримання прибутку виробництвами сільського зеленого туризму в Україні. Похвальним $€$ скорочення фрактичних витрат 3 117,2 до 104,4 грн. за один день перебування. Це - один із фракторів імовірного зростання чисельності візитерів, оскільки, коефріцієнт використання місткості сільських садиб лишається низьким - 0,19. Тому ринок сільського зеленого туризму лишається ненасиченим, водночас як під час сезону в закладах розміщення відпочиваючих фратально не вистачає місць. Проте, у
2017 р. за всіма показниками відбулося зростання, окрім коефіцієнту використання місткості садиб, котрий у 2017 р. зменшився до 0,2 порівняно з 2012 р. [1; 4].

Висновки. Отже, завдання, котрі постають перед туристичними підприємствами як безпосередніми виробниками туристичного продукту, закладами вищої освіти, громадськими організаціями, товариствами, виробництвами різних галузей, полягають в: об'єднанні зусиль фрахівців різних галузей господарської діяльності, товариств, громадських організацій та наукових установ щодо ініціювання інноваційного туристичного кластеру для забезпечення продуктивного розвитку внутрішнього та в"їзного туризму; модернізації програм, турів, маршрутів із надання туристичних та рекреаційних послуг; імплементації туристичних продуктів кластеру в національній туристичній практиці. Перспективними напрямами вбачається дослідження питання диверсисрікації інших видів туристичного продукту.

\section{СПИСОК ВИКОРИСТАНИХ ДЖЕРЕЛ:}

1. Безкоровайна Л.В., Бойка О.А., Омельянчик О.В. Сільський туризм, біорізноманіття та сталий розвиток: комплементарність та вплив на добробут сільського населення. Економічний вісник Дніпровської політехніки : Науковий журнал. Серія : Економічна теорія. 2021. № 1(73). C. 68-76. DOI: https://doi.org/10.33271/ ebdut/73.068

2. Безкоровайна Л.В. Теоретичні і методичні засади професійної підготовки майбутніх фрахівців з туризмознавства у вищих навчальних закладах : дис. ... д-ра пед. наук : 13.00 .04 / Запорізький національний університет. Запоріжжя, 2018. 713 c. URL: http://phd.znu.edu.ua/page//dis/09_2018/Bezkorovaina_dis.pdf

3. Зінчук Т.О., Куцмус Н.М. Диверсифікація бізнесу на сільських територіях: досвід країн світу. Економіка АПК. 2018. № 4. C. 19-27. URL: http://eapk.org.ua/sites/default/files/eapk/2018/04/eapk_2018_4_p_19_27.pdf

4. Колективні засоби розміщування в Україні в 2012, 2013 та 2014 роках. Державна служба статистики України. URL: http://www.ukrstat.gov.ua

5. Resolution adopted by the General Assembly on 22 December 2015 (2015). Global Code of Ethics for Tourism. URL: https://undocs.org/ru/A/RES/70/200 
6. The Paris Agreement under the United Nations Framework Convention on Climate Change. United Nations. 12 December 2015 (2015). URL: https://www.un.org/ru/climatechange/paris-agreement

\section{REFERENCES:}

1. Bezkorovaina L.V., Boika O.A., Omelianchyk O.V. (2021) Silskyi turyzm, bioriznomanittia ta stalyi rozvytok: komplementarnist ta vplyv na dobrobut silskoho naselennia. Ekonomichnyi visnyk Dniprovskoi politekhniky: Naukovyi zhurnal. Seriia: Ekonomichna teoriia, no. 1(73), pp. 68-76. DOI: https://doi.org/10.33271/ebdut/73.068 (in Ukrainian)

2. Bezkorovaina L.V. (2018) Theoretical and methodological basis of the professional training of the future masters of tourism in higher educational institutions. Thesis for a doctoral degree in pedagogical sciences, Zaporizhzhia: Zaporizhzhia National University. (in Ukrainian)

3. Zinchuk T.O., Kutsmus N.M. (2018) Dyversyfikatsiia biznesu na silskykh terytoriiakh: dosvid krain svitu. Ekonomika APK, no. 4, pp. 19-27. Available at: http://eapk.org.ua/sites/default/files/eapk/2018/04/eapk_2018_ 4_p_19_27.pdf (in Ukrainian)

4. Kolektyvni zasoby rozmishchuvannia v Ukraini v 2012, 2013 ta 2014 rokakh. Derzhavna sluzhba statystyky Ukrainy. Available at: http://www.ukrstat.gov.ua (in Ukrainian)

5. Resolution adopted by the General Assembly on 22 December 2015 (2015). Global Code of Ethics for Tourism. Available at: https://undocs.org/ru/A/RES/70/200

6. The Paris Agreement under the United Nations Framework Convention on Climate Change. United Nations. 12 December 2015 (2015). Available at: https://www.un.org/ru/climatechange/paris-agreement 